
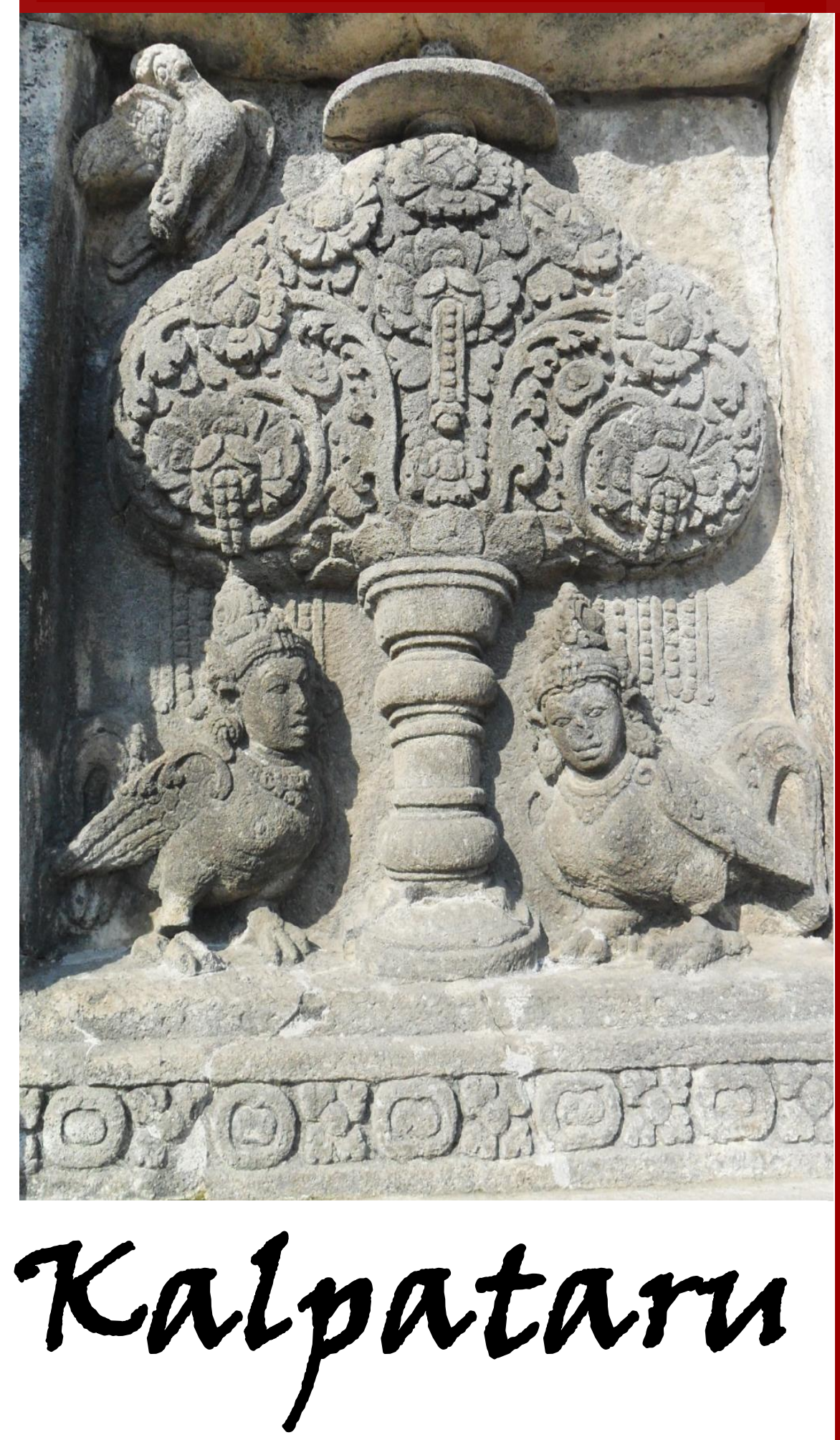

JURNAL SEJARAH DAN PEMBELAJARAN SEJARAH

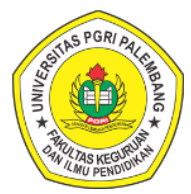

Program Studi Pendidikan Sejarah Jurusan Pendidikan IPS

Fakultas Keguruan dan IImu Pendidikan Universitas Persatuan Guru Republik Indonesia Palembang
Pengaruh Penerapan Model Project Based Learning Berbasis Video Vlog Dalam Proses Pembelajaran Sejarah Farena Adela, Nur Ahyani, Dina Sri Nindiati

Identifikasi Nilai Pedagogi Pada Pahatan Monolid Desa Jarakan Sebagai Sumber Pembelaran Sejarah Alzata Putra, Sukardi, Aan Suriadi

Nilai Sejarah Makam Puyang Ulak Laut di Pecah Pinggan Sebagai Sumber Pembelajaran Sejarah Berbasis Digital Dewi Cahya, Sukardi, Eva Dina Chairunisa

Pola Sebaran Permukiman di Kota Kayu Agung

I Made Lingga Wardana, Sukardi, Wandiyo

Peran Adam Malik Sebagai Ketua Sidang Majelis Umum PBB 1971 Rani Noviyanti

Pemanfaatan Foto dan Arsip Sebagai Sumber Pembelajaran Sejarah Riki Andi Saputro, Muhammad Fitri

Nilai-Nilai Sejarah Puyang Muara Rambang Sebagai Sumber Pelajaran Sejarah Lokal di SMA 01 Muarakuang Dwi Cahyati, Sukardi, Eva Dina Chairunisa

Pemikiran Abdul Mukti Ali Sebagai Sumber Pembelajaran Sejarah di SMA Patra Mandiri 1 Palembang Andika Merryanto Saputra, Aan Suriadi, Ahmad Zamhari

Perjuangan Hj. Rangkayo Rasuna Said Sebagai Pejuang Politik dan Pemikir Pergerakan Pada Masa Pra Kemerdekaan

Narani Agesti, Ageng Sanjaya

Nilai Sosial Religi Tradisi Manopeng Pada Masyarakat Banyiur Muhammad Fitri, Heri Susanto 
Kalpataru, Volume 7, Nomor 2, Desember 2021 (153-160)

\title{
PERJUANGAN HJ. RANGKAYO RASUNA SAID SEBAGAI PEJUANG POLITIK DAN PEMIKIR PERGERAKAN PADA MASA PRA KEMERDEKAAN
}

\author{
Narani Agesti \\ Program Studi Pendidikan Sejarah, Universitas Veteran Bangun Nusantara Sukoharjo \\ Email: naraniagesti103@gmail.com \\ Ageng Sanjaya \\ Program Studi Pendidikan Sejarah, Universitas Veteran Bangun Nusantara Sukoharjo
}

\begin{abstract}
ABSTRAK
Penelitian ini bertujuan untuk mengetahui bentuk perjuangan politik yang dilakukan $\mathrm{Hj}$. Rangkayo Rasuna Said, Mengetahui peran Hj. Rangkayo Rasuna Said dalam pergerakan dan perjuangan yang dilakukan serta untuk mengetahui nilai-nilai yang terkandung dalam pemikirannya. Penelitian dan penulisan mengenai perjuangan $\mathrm{Hj}$. Rangkayo Rasuna Said sebagai pejuang politik dan pemikir pergerakan pra kemerdekaan menggunakan metode penelitian Historis. Dari hasil penelitian ini maka dapat ditarik satu kesimpulan bahwa Hj. Rangkayo Rasuna Said merupakan pejuang wanita yang bergerak di bidang politik dan tertarik pada dunia politik di usianya yang masih remaja yaitu 16 tahun, Rasuna Said yang aktif di dunia politik hingga akhirnya ia ditangkap sebab kritik yang dilontarkan kepada penjajah pada saat itu. Peranan yang dimainkan oleh Rasuna Said dimulai dari sekretaris organisasi, orator, pimpinan majalah, dan pemimpin pergerakan pemuda di masa penjajahan Belanda dan Jepang. Serta ada nilai-nilai yang dapat diambil pula pada perjuangan $\mathrm{Hj}$. Rangkayo Rasuna Said di antaranya Feminisme, Nasionalisme dan Patriotisme, dan Persatuan serta perjuangan.
\end{abstract}

Kata Kunci: Hj. Rangkayo Rasuna Said, Pejuang, Pergerakan, Politik, Pra Kemerdekaan.

\section{A. PENDAHULUAN}

Kemerdekaan yang dirasakan sampai pada hari ini, tentu tidak terlepas dari perjuangan pahlawan. Kemerdekaan juga merupakan buah tulus dari pengorbanan dan semangat dari para pahlawan. Masa penjajahan Belanda muncul begitu banyaknya perempuanperempuan yang berjuang tanpa gentar dan saling bahu membahu dengan kaum laki-laki untuk mengusir penjajah (Widi, 2013:12). Ada begitu banyak tokoh-tokoh perempuan yang dilahirkan di negeri ini, tetapi sayangnya banyak yang tidak tahu bahwa ada salah seorang pejuang wanita yang tetap berpendirian kepada nilai-nilai agama yaitu $\mathrm{Hj}$. Rangkayo Rasuna Said (Jahroni, 2002:68).

Salah satu dari banyaknya pejuang wanita di Indonesia yang patut untuk diteladani adalah $\mathrm{Hj}$. Rangkayo Rasuna Said, ada sesuatu hal yang cukup menarik dari bentuk perjuangannya yaitu ia sangat ingin mengangkat kesetaraan kaum wanita agar memiliki kedudukan yang sama dengan derajat kaum laki-laki dan tidak dipandang sebelah mata yang oleh masyarakat yang mengatakan kodrat wanita hanya urusan dapur dan rumah tangga $\mathrm{Hj}$. Rangkayo Rasuna Said sangat memperhatikan kemajuan dan pendidikan kaum wanita, terbukti $\mathrm{Hj}$. Rangkayo Rasuna Said pernah mengajar di Sekolah Diniyah Putri yang didirikan oleh ibu Rahmah EI Yunusi pada tahun 1923 di Padang Panjang. Pada tahun 1926 Rasuna Said memiliki sebuah pandangan bahwa kemajuan untuk kaum wanita tidak hanya di dapat dari dunia pendidikan tetapi harus disertai dengan perjuangan dibidang politik (Kamajaya, 1984:75).

Pada tahun 1926 terjadi bencana alam di Padang Panjang, membuat Rasuna kembali ke Maninjau. Di Maninjau ia tidak tinggal diam dan mulai belajar di sekolah yang dipimpin oleh $\mathrm{H}$. Abdul Majid dari golongan "Kaum Tua". Disebabkan Rasuna Said yang merasa tidak memperoleh dalam keserasian jiwa, akhirnya Rasuna Said pindah belajar di Sekolah "Thawalib" di Panyinggahan Maninjau, sekolah 


\section{Kalpataru, Volume 7, Nomor 2, Desember 2021 (153-160)}

yang didirikan oleh perkumpulan Islam "Sumatra Thawalib" yang menganut pada paham nasionalisme dan berhaluan radikal (Kamajaya, 1984:75). Tahun 1930 didirikanlah PERMI oleh perhimpunan "Sumatra Thawalib" yang bergerak dibidang sosial dan pendidikan dengan haluan radikal non-koprasi (Kamajaya, 1984). Rasuna Said berpidato dihadapan rakyat, dan Rasuna dituduh menghasut rakyat untuk memberontak sehingga di tahun 1932 Rasuna Said dijatuhi hukuman penjara 1 tahun 2 bulan di Bulu, Semarang. Hal ini menyebabkan menyebabkan PERMI bubar pada tahun 1937 (Kowani, 1978:13).

Pergerakan Rasuna Said adalah salah satu bentuk dalam menegakkan kesetaraan gender yang selama ini yang mendorong Rasuna Said untuk melakukan sebuah perjuangan, keinginannya untuk menyuarakan emansipasi kaum wanita. Rasuna Said lakukan untuk mengangkat tinggi harkat dan martabat wanita agar setara dengan kaum laki-laki dan Rasuna Said melakukan pergerakan politik untuk memperjuangkan kemerdekaan Indonesia. Melalui perjuangan-perjuangan politik dan pergerakan yang dilakukan Rasuna Said yang membuat ia disegani pemerintah Kolonial (Jahroni, 2002:72).

\section{B. METODE PENELITIAN}

Penelitian ini merupakan sebuah
penelitian yang berusaha untuk merekonstruksikan, mendiskripsikan, dan memaparkan perjuangan politik dan pemikiran dari pergerakan $\mathrm{Hj}$. Rangkayo Rasuna Said pada masa pra kemerdekaan. Mengingat peristiwa yang menjadi pokok penelitian adalah peristiwa yang terjadi di masa lampau sehingga metode Historis dipilih untuk metode penelitian ini. Dengan metode sejarah penulis mencoba merekonstruksi kembali suatu peristiwa di masa lampau sehingga dapat menghasilkan historiografi sejarah yang dapat dipertanggung jawabkan secara ilmiah. Dalam perkembangan penulisan dan pelajaran Sejarah Indonesia dewasa ini ternyata dirasakan sangat perlu untuk memikirkan serta menyusun metodologi yang sesuai dengan corak Sejarah Indonesia (Kartodirdjo, 1982:68). Metode sejarah adalah suatu proses menguji dan menganalisa secara kritis rekaman dan peninggalan masa lampau (Louis Gottshalck,1983:32).

Analisis Historis dipilih untuk digunakan dalam teknik analisis data. Menurut Kuntowijoyo (1999:64), penafsiran atau interpretasi sejarah sering disebut dengan analisis sejarah. Analisis sendiri berarti menguraikan, dan secara terminologis berbeda dengan sintesis yang berarti menyatukan. Analisis dan sintesis juga dipandang sebagai metode utama dalam sebuah interpretasi. Menurut Helius Syamsuddin (1996: 89) teknik analisis data historis merupakan analisis sejarah yang menggunakan kritik sumber sebagai metode untuk menilai sebuah sumber yang digunakan dalam penulisan sejarah.

Dalam pengumpulan data dipergunakan teknik studi pustaka, yaitu pengumpulan data yang dilakukan dengan melakukan seleksi pada data tertulis dengan membaca dan mengumpulkan arsip-arsip ataupun dokumen, membaca surat kabar, majalah, dan buku-buku literatur. Dengan teknik ini, peneliti melakukan kunjungan keperpustakaan untuk mendapatkan sumber buku yang cukup relevan dengan penelitian yang sedang dilakukan, karena salah satu hal yang perlu dilakukan dalam persiapan penelitian adalah memanfaatkan dan memaksimal sumber informasi yang terdapat pada perpustakaan dan jasa informasi yang ada. Adapun kegiatan studi pustaka yang dilakukan, yaitu dengan memanfaatkan berbagai perpustakaan di lingkup Universitas Veteran Bangun Nusantara dan perpustakaan yang ada di daerah Surakarta. Kegiatan pengumpulan data ini juga dilakukan di Perpustakaan Universitas Veteran dan sekitarnya juga memanfaatkan akses secara online dari rumah mengingat kondisi selama darurat Covid-19.

\section{HASIL DAN PEMBAHASAN Latar Belakang Kehidupan $\mathrm{Hj}$. Rangkayo Rasuna Said}

Pada tanggal 14 September 1910 tepatnya di Panyinggahan sebuah desa yang letaknya tidak jauh dari Maninjau lahirlah Rasuna Said putri dari H. Mahmud Said. Sedangkan "Rangkayo" merupakan gelar kebangsawanan yang diberikan setelah Rasuna 


\section{Kalpataru, Volume 7, Nomor 2, Desember 2021 (153-160)}

Said menikah. Keluarga besar Haji Said merupakan keluarga yang cukup terpandang di kalangan masyarakat, mereka dikenal sebagai penganut agama Islam yang taat dan sangat memperhatikan anak-anaknya (Kamajaya, 1984:75). Pada umumnya, anak-anak keluarga Haji Said bersekolah di sekolah umum yang didirikan oleh Belanda. Berbeda dengan Rasuna Said, ia lebih memilih bersekolah di sekolah agama yang terletak di dekat rumahnya. Kesibukan ayah Rasuna Said sebagai pengusaha, yang menyebabkan ayahnya tidak mempunyai waktu untuk mengurus putrinya sehingga sejak kecil Rasuna diasuh oleh keluarga kakak ayahnya. Rasuna Said memiliki saudara tiri bernama Bachtaruddin (Esti, 2017:6).

Rasuna mendapatkan pendidikan dasar disebuah sekolah agama, selepas sekolah ia belajar di Pesantren Ar-Rasyidiyah yang dipimpin oleh Syekh Abdul Rasyid. Di pesantren ini Rasuna Said merupakan siswi wanita satusatunya, ia belajar berbagai ilmu keislaman seperti tauhid, fikih, hadits, dan bahasa Arab sampai tingkat mahir. Sangat disayangkan, belum puas menimba ilmu kepada sang guru, tuan Syekh Abdul Rasyid meninggal dunia. Rasuna kemudian melanjutkan sekolahnya di sekolah Diniyah Putri Padang Panjang yang dipimpin oleh Zainuddin Labai El-Yunusi. Rasuna Said dididik oleh Zainuddin dalam kurun waktu yang singkat, setelah kematian Zainuddin sekolah Diniyah Putri dikelola oleh Rahmah adik dari Zainuddin. Di sekolah inilah Rasuna dan Rahmah untuk pertama kali bertemu, dua orang wanita inilah yang paling terkenal di Minangkabau. Rasuna dapat menyelesaikan pendidikannya dengan lancar, ketika berada di kelas 5 dan 6 Rasuna diberikan tugas untuk mengajar di kelas-kelas yang lebih rendah (Jahroni, 2002:71). Pada 28 Juni 1926 terjadi bencana alam di Padang Panjang, yang menyebabkan para siswa harus dipulangkan ke kampung halaman masing-masing (Kamajaya, 1984:75). Rasuna Said juga pernah bersekolah di sekolah yang dipimpin oleh Haji Abdul Majid, dengan waktu yang singkat. Kemudian, Rasuna melanjutkan pendidikannya di sekolah Putri (Meisjessschool) untuk memperoleh keahlian memasak, menjahit, dan urusan rumah tangga lainnya. Perjalanan pendidikan Rasuna cukup panjang dan banyak dengan pengalaman untuk wanita pada masa itu (Jahroni, 2002:75).

Bakat dan kepandaian Rasuna mendukungnya untuk memasuki pergerakan rakyat, Rasuna yang memiliki sifat ikhlas dan jujur sehingga terpenuhi syarat sebagai pemimpin pergerakan rakyat. Pada tahun 1926 Rasuna mengikuti perkumpulan "Sarikat Rakyat" (SR) kemudian berubah menjadi (Partai Serikat Islam Indonesia). Rasuna pun menjadi anggota dan duduk menjadi anggota PERMI (Persatuan Muslimin Indonesia), namun Rasuna lebih memilih PERMI sebab keberhasilan PERMI dalam menyebarluaskan pengaruhnya ke seluruh daerah Sumatera Barat, karena PERMI mempunyai pelopor-pelopor pejuang di Sumatera Barat (Kamajaya, 1984:77).

\section{Bentuk Perjuangan Politik $\mathrm{Hj}$. Rangkayo Rasuna Said}

Setelah Rasuna dikeluarkan dari Diniyah Putri, ia menyibukkan diri untuk mendalami agama kepada tokoh-tokoh pembaharu Minangkabau. Dengan bimbingan Haji Rasul membuat pemikiran Rasuna semakin terbuka, setelah beberapa tahun belajar dengan Haji Rasul dan juga mengikuti sekolah putri (Meijes School) pada tahun 1926 terjadi bencana alam di Padang Panjang membuat Rasuna pulang ke kampung halamannya di Maninjau (Sally, 2013:37). Setelah kembali ke kampung halaman Rasuna bersekolah di sekolah yang dipimpin oleh H. Abdul Majid dari golongan "Kaum Tua", namun di sana Rasuna merasa tidak memperoleh kecocokan di sana. Rasuna lalu bergabung dengan sekolah Thawalib yang didirikan oleh sekelompok orang yang menamakan dirinya Kaum Muda (Kamajaya, 1984:75). Di sekolah inilah sifat dan kepribadian Rasuna dibentuk sebagai seorang calon pejuang kaum wanita. Rasuna yang diajarkan menjadi orator ulung untuk menyampaikan aspirasi-aspirasi di dalam pidato-pidatonya (Martamin, 1977:139).

Masuknya Rasuna Said dalam Sarekat Rakyat sebagai pengurus, penulis, dan sekretaris. Organisasi ini menggalang kekuatan masyarakat untuk melawan penjajahan Hindia Belanda. Namun Datuk Ibrahim Tan Malaka 


\section{Kalpataru, Volume 7, Nomor 2, Desember 2021 (153-160)}

yang kala itu bergerak sebagai propagandis komunis dari Payakumbuh banyak memanfaatkan Sarikat Rakyat untuk tujuan politik. Sehingga pada tahun 1927 terjadilah pemberontakan komunis yang meletus di Silunggkang, atas peristiwa itu cukup banyak rakyat kecil yang menjadi korban (Jahroni, 2002:76). Akhirnya pada tahun 1930 Sarikat Rakyat resmi berubah menjadi Partai Sarikat Islam Indonesia (PSII) (Jahroni, 2002:77).

Setelah Sarikat Rakyat berubah menjadi partai politik dengan nama Partai Serikat Islam Indonesia (PSII). Namun pada saat yang sama perhimpunan Sumatera Thawalib pada konferensinya pada tanggal 22-27 Mei 1930 menyatakan telah mendirikan partai politik bernama Persatuan Muslim Indonesia (PERMI). Karena PERMI menjadi partai politik dan PSII juga merupakan partai politik, di mana Rasuna Said pun menjadi anggota kedua partai tersebut dan terkena disiplin peraturan oleh PSII yang ditetapkan pada kongres tahun 1921 yang menyebutkan bahwa setiap anggotanya dilarang merangkap dari partai politik. Rasuna mematuhi hal tersebut Rasuna dengan memantapkan pilihannya untuk memilih PERMI, yang demikian Rasuna keluar dari PSII dan tetap menjadi anggota PERMI (Kamajaya, 1984:77). Pada tahun 1932 PERMI yang resmi menjadi partai politik tidak lepas dari 3 serangkai anak Minang yaitu, Haji llyas Yakub, Haji Mukhtar Lutfhi, dan Haji Jalaluddin Thaib. Partai PERMI yang berlandaskan Islam dan kebangsaan dengan cepat mendapatkan simpati rakyat yang bukan hanya berasal dari Sumatera Barat tapi gaungannya sampai ke daerah Tapanuli, Bengkulu, Palembang, dan Lampung (Jahroni, 2002:77).

Di dalam PERMI kegiatan Rasuna Said sangat menonjol, demikian pula ketangkasannya teruji. Bahkan Rasuna Said memberikan kursus di antaranya adalah, pelajaran berpidato, dan berdebat sebagai latihan ketajaman pikiran bagi kader-kader PERMI di mana ia memberikan ceramah untuk para anggota PERMI dengan berpidato di muka umum membentangkan azas dan tujuan partainya, yaitu nasionalisme yang berjiwa Islam dan berhaluan non koperasi untuk mencapai Indonesia merdeka (Putra, 2019:41). Rasuna
Said sebagai ahli pidato dari partai PERMI banyak belajar dari kedua pemimpin besar pada saat itu yaitu Bung Karno dan Bung Hatta lewat surat menyurat, pada saat itu Rasuna Said merasa mendapat bimbingan langsung dari kedua pemimpin terebut dalam meneruskan perjuangannya (Kamajaya, 1984:78). Kemampuan pidato Rasuna Said yang ia dapatkan dari gurunya $\mathrm{H}$. Udin Rahmani sewaktu ia menimba ilmu di Sumatera Thawalib ternyata sangat membantu aktivitas propaganda partai politiknya kemampuan Rasuna Said dalam berpidato mampu menarik simpati rakyat datang berbondong-bondong mendengarkan ceramah politiknya bahkan agen-agen PID selalu mengincar dan mengikuti gerak-geriknya bahkan tak jarang juga di tengah-tengah pidatonya Rasuna Said dipaksa berhenti dan diturunkan dari podium. Karena keberaniannya mengkritik pemerintah Hindia Belanda banyak yang menjulukinya "Singa Betina" (Jahroni, 2002:78). Setelah Rasuna Said memberikan pidato-pidato yang sangat keras mengkritik pemerintah Hindia Belanda di Payakumbuh membuat ia ditangkap satu hari setelah pidatonya tersebut. Pada saat menjalani masa hukumannya, murid Rasuna Said terkena Spreek Delict oleh pemerintah Hindia Belanda. (Sally, 2013:108).

Setelah peristiwa penangkapan Rasuna Said pemerintah Hindia Belanda selanjutnya mengadakan kontrol yang sangat ketat terhadap segala macam bentuk penerbitan, pidato, dan khotbah di masjid-masjid, lalu pengawasan terhadap aktivis-aktivis PERMI. Tokoh-tokoh PERMI satu persatu bernasib sama seperti Rasuna Rasimah Ismail seorang propagandis PERMI dan murid dari Rasuna juga terkena Spreek Delict di Sungai Puar Bukittinggi, lalu guru Rasuna di Sumatera Thawalib yaitu Zainal Abidin Ahmad dan Duski Samad dihukum tidak boleh mengajar lagi di Sumatera Thawalib. Sedangkan tiga serangkai PERMI pada tahun 1934 mereka juga ditangkap, Muchtar Luthfi dibuang ke Makassar sedangkan llyas Yakub dan Jalaludin Thaib dibuang ke Digul (Sally, 2013:111).

Pada tahun 1935 setelah beberapa waktu mejalani hukumannya, Rasuna lalu kembali pulang ke daerah asalnya yaitu kota Padang. 


\section{Kalpataru, Volume 7, Nomor 2, Desember 2021 (153-160)}

Kemudian Rasuna Said meneruskan pendidikannya di sekolah Islamic College yang dipimpin oleh K.H. Mochtar Jahja dan Dr. Kusuma Atmaja, di lembaga ini ia mempelajari berbagai macam pengetahuan. Di tahun yang sama Rasuna Said sempat memimpin sebuah koran yang bernama "Raya" koran yang sangat nasionalis dan radikal. Koran ini merupakan obor perlawanan bagi kebangkitan pergerakan nasionalis rakyat di Sumatera Barat. Namun PID atau polisi pemerintah Hindia Belanda mempersempit ruang gerak media koran tersebut (Sally, 2013:111). Karena gerak dan langkah PERMI sangat dibatasi oleh macammacam peraturan dan larangan sehingga PERMI tidak dapat berkutik. Akhirnya tidak ada jalan lagi bagi PERMI untuk melakukan pergerakan kecuali membubarkan diri pada tanggal 18 Oktober 1937 (Martamin, 1977:73).

Bubarnya PERMI merupakan pukulan keras bagi Rasuna Said, ia tidak setuju atas pembubaran partainya. Dengan bubarnya PERMI Rasuna Said pergi meninggalkan tanah kelahirannya. Kemudian ia pindah ke Kota Medan, Sumatera Utara dan di kota itulah Rasuna Said meneruskan perjuangannya dengan cara yang lain tetapi tujuan tetap sama yaitu Kemerdekaan Indonesia. Di Kota Medan pergerakan yang Rasuna Said lakukan yaitu, mendirikan sebuah lembaga pendidikan khusus untuk kaum wanita dan yang kedua ia menerbitkan sebuah majalah (Kamajaya, 1984:80).

\section{Peran Hj. Rangkayo Rasuna Said dalam Perjuangan Kemerdekaan Indonesia}

Pada saat Rasuna Said bersekolah di Diniyah Putri, ia menyelesaikan sekolahnya dengan lancar bahkan Rasuna sudah diberikan tugas-tugas untuk mengajar di kelas yang berada di bawahnya. Namun dalam proses pembelajarannya Rasuna kemudian memberikan pelajaran tentang politik-politik yang membuat ia tidak sejalan dengan pemimpian Sekolah Diniyah Putri yaitu Rahmah El-Yunusi (Jahroni, 2002:73).

Berkat kepandaian dan sifat jujur dan ikhlasnya ia memenuhi syarat sebagai pemimpin pergerakan rakyat yang berhaluan keras radikal dan berlandaskan tabiat untuk berterus terang, baik dengan lawan maupun kawan membuat ia bergabung ke Sarikat Rakyat. Bergabungnya Rasuna Said dengan Sarikat Rakyat pada tahun 1926 tidak hanya sebagai anggota namun juga sebagai sekretaris ataupun penulis, namun pada saat yang sama ia menjadi anggota partai politik PERMI yang didirikan oleh perhimpunan Sumatera Thawalib. Rasuna yang menjadi bagian dari dua partai politik lebih memilih PERMI sebagai Haluan partainya (Kamajaya, 1984:77). Rasuna yang terkenal sebagai ahli pidato atau orator membuat namanya semakin terkenal bersamaan dengan meningkatnya eksistensi partai PERMI di pelosok-pelosok Sumatera Barat. Tidak cukup sampai disitu Rasuna Said yang mendirikan pendidikan rakyat seperti kursus pemberantasan buta huruf dengan nama sekolah "Menyesal", Sekolah Thawalib Putri dan kursus putri yang mana sekolah itu juga dididik oleh kader-kader partai PERMI. Atas jasanya mendirikan sekolah rakyat membuat rakyat di pedesaan mengenal partai PERMI dengan Rasuna Said nya. Sekolah-sekolah yang telah dibangun di Bukittinggi itu kemudian putra menyebar di seluruh Sumatera Barat, bahkan sampai di Tapanuli, Bengkulu, dan Lampung (Kamajaya, 1984:78). Pengaruh Rasuna Said dengan kepandaian dan kegiatan-kegiatannya membuat pengaruh Rasuna Said semakin besar dikalangan masyarakat. Sehingga membuat ia menjadi target operasi PID. Pada puncaknya ia ditangkap dan dimasukan ke penjara di Bulu, Semarang, Jawa Tengah (Kamajaya, 1984:78).

Setelah beberapa tahun keluar dari penjara pada tahun 1935 dan sempat berguru di Islamic Collage dan menjabat sebagai pimpinan redaksi majalah "Raya". Akhirnya pada tahun 1938 Rasuna meninggalkan tanah kelahirannya dan menuju kota Medan, Sumatera Utara dengan harapan dapat meneruskan kembali perjuangannya. Di Kota Medan Rasuna kembali meneruskan perjuangannya dengan cara lain tetapi tujuan yang sama yaitu kemerdekaan Indonesia. Rasuna Said merintis jalannya sendiri dengan mendirikan Perguruan Putri dan majalah Menara Putri (Sally, 2013:112).

Pada bulan Februari 1942, Jepang memulai invasinya di Sumatera dengan pasukan-pasukan mereka di Palembang 


\section{Kalpataru, Volume 7, Nomor 2, Desember 2021 (153-160)}

dengan maksud untuk mendahului rencana bangsa Belanda yang akan merusak instalasi minyak. Kedatangan bangsa Jepang ke Indonesia telah tercium oleh pemerintah Belanda. Tantara bangsa Jepang memasuki Kota Padang pada 17 Maret 1942 (Kahin, 2008:135). Belanda memperkirakan akan terjadi persaingan besar jika bangsa Jepang benarbenar datang ke Indonesia, untuk mempersiapkan hal tersebut Belanda melakukan latihan militer di mana-mana. Belanda membentuk pasukan khusus seperti, Pasukan Pengawal Negeri (Stadswacht), Pasukan Pengawal Udara (Luchtbechermings Dients). Namun saat kedatangan bangsa Jepang ke Indonesia Belanda tidak melakukan perlawanan apapun. Sebelum pendaratan, para tantara Jepang menghancurkan Kota Padang dan Pelabuhan Teluk Bayur. Hal tersebut menyebabkan seluruh pasukan Belanda lumpuh total. Sebelum meninggalkan Sumatera Barat Belanda melakukan taktik dengan menghancurkan jalan, jembatan, dan bangunan penting lainnya, dan dibeberapa kota seperti Payakumbuh dan Batusangkar terjadi kebakaran yang hebat (Jahroni, 2002:84).

Tidak lama setelah kedatangan bangsa Jepang Rasuna Said kembali ke Minang untuk melakukan pergerakan. Bersama Chotib Sulaiman Rasuna mendirikan "Pemuda Nippon Raya" demi menyatukan pemuda Sumatera Barat (Kahin, 2008:148). Berdirinya organisasi ini mereka bekerja sama dengan pemerintah Jepang, namun pada hakekatnya untuk membentuk kader demi perjuangan kemerdekaan. Sebuah cita-cita yang terkadang tidak disembunyikan oleh para pemimpin pemuda itu, terutama Rasuna Said. Setelah mengetahui cita-cita sebenarnya dari "Pemuda Nippon Raya" maka organisasi itu dibubarkan oleh pihak Jepang (Kamajaya, 1984:81). Setelah di pulau Jawa dibentuk Heiho dan PETA (Pembela Tanah Air), maka para tokoh pergerakan di Sumatera Barat juga memberikan usulan kepada pemerintah Jepang untuk membentuk Gyu Gun. Gyu Gun dibentuk dengan pimpinannya adalah Chotib Sulaeman, sedangkan Rasuna Said ditunjuk sebagai pemimpin bagian putri dengan nama "Butuh Ibu Pusat Laskar Rakyat" (Kamajaya, 1984:82).
Rasuna Said bertanggung jawab dibagian propaganda organisasi. Rasuna berperan penting dalam melebarkan sayap Gyu Gun ke seluruh pelosok daerah Sumatera Barat, seperti Padang Panjang, Bukittinggi, Payakumbuh, Sijunjung, Batusangkar, Maninjau, Pariaman, Kerinci, dan Panian untuk memperkenalkan organisasi yang merekrut masa sebanyak-banyaknya (Jahroni, 2002:85). Dalam kegiatan propagandanya Rasuna Said membentuk kader perjuangan bangsa, dan kader yang telah mendapat didikan kemudian menjadi tokoh-tokoh dalam Badan Keamanan Rakyat (BKR), lalu berganti nama menjadi Tentara Kemanan Rakyat (TKR), dan menjadi Tentara Republik Indonesia (TRI), dan pada akhirnya menjadi Tentara Nasional Indonesia (TNI) (Kamajaya, 1984:82).

\section{Nilai-Nilai yang Terkandung dalam Pemikiran Rasuna Said}

Nilai perjuangan yang terkandung dalam pergerakan yang digaungkan oleh $\mathrm{Hj}$. Rangkayo Rasuna Said dibuktikan ketika Rasuna Said menginginkan pendidikan bagi seluruh masyarakat terutama bagi kaum wanita. Hal ini dibuktikan ketika Rasuna mengajar di Diniyah Putri, di mana pada saat itu Rasuna Said mengajarkan tentang politik terhadap siswinya bahwa wanita tidak hanya memenuhi kodratnya untuk menikah lalu memiliki keturunan. Rasuna Said mengajarkan juga bahwa pentingnya memahami politik bagi wanita agar mereka ikut dalam jalan perjuangan menuju Indonesia merdeka. Tidak hanya mengajarkan politik, Rasuna Said juga mendirikan sekolah khusus untuk wanita salah satunya adalah sekolah "Menyesal".

Nilai nasionalisme dan patriotisme yang ditunjukan dari bentuk perjuangan $\mathrm{Hj}$. Rangkayo Rasuna Said terlihat ketika Belanda menjajah masyarakat Minangkabau dan pada saat itu $\mathrm{Hj}$. Rangkayo Rasuna Said dengan pemudapemuda asal Minangkabau yang tergabung di Sarikat Rakyat berjuang untuk membela negara Indonesia dengan semangat perjuangannya membela kaum tertindas dan masyarakat biasa. Para pejuang bangsa Indonesia yang berada di tanah Minangkabau, terutama Rasuna Said ada di dalamnya berjuang melawan penjajah 


\section{Kalpataru, Volume 7, Nomor 2, Desember 2021 (153-160)}

dikarenakan kecintaan mereka terhadap kemerdekaan tanah air, bangsa dan negara Indonesia sebagai bentuk semangat nasionalisme dan patriotisme.

Nilai persatuan yang terkandung dalam perjuangan Rasuna Said yaitu dengan adanya semangat yang dimiliki Rasuna Said untuk terus mempersatukan keinginan dan keyakinan membebaskan diri dari penjajahan. Cara yang ditempuh Rasuna Said pada saat itu adalah dengan membuat tulisan-tulisan di majalah "Raya", sebab pada saat Rasuna Said keluar dari penjara ia melihat semangat pemudapemuda Minangkabau yang surut untuk melakukan perjuangan menuju Indonesia merdeka. Berbagai upaya dilakukan, berbuah manis usahanya tersebut semata-mata masyarakat Minangkabau kembali mengobarkan semangatnya untuk terus berjuang bersama dengan kaum pergerakan lainnya guna mnecapai Indonesia merdeka.

\section{SIMPULAN}

1. Hj. Rangkayo Rasuna Said lahir pada tanggal 14 September 1910 yang merupakan putri dari $\mathrm{H}$. Mahmud Said. Keluarga H. Mahmud Said merupakan keluarga yang sangat terpandang pada saat itu karena ketaatannya menjalankan ajaran agama Islam. H. Mahmud Said ayah yang sangat memperhatikan pendidikan semua anak-anaknya, terbukti dengan semua anak-anaknya bersekolah di sekolah umum yang didirikan Belanda.

2. Organisasi politik pertama yang diikuti Rasuna Said adalah Sarikat Rakyat dan Sumatera Thawalib yang di mana kedua organisasi tersebut dikemudian hari berubah menjadi partai politik. Sarikat Rakyat yang berubah menjadi PSII (Persatuan Sarikat Islam Indonesia) dan PERMI (Persatuan Muslimin Indonesia). Rasuna terlibat banyak dalam perjuangan di partai PERMI, salah satunya sebagai seksi propaganda antar partai, ahli pidato partai dan menyebar luaskan partai PERMI hingga ke pelosok-pelosok Sumatera Barat dengan membuka sekolah seperti sekolah "Menyesal", sekolah "Thawalib Putri", dan "Kursus Putri". Rasuna yang sempat dipenjara karena terkena Spreek Delict kemudian menjadi penulis majalah "Raya" setelah bebas dari hukumannya, setelah mendengar kabar PERMI yang bubar Rasuna Said melanjutkan perjuangannya di Kota Medan, Sumatera Utara. Di Kota Medan ia mendirikan pendidikan "Perguruan Putri" dan juga sebuah majalah "Menara Putri", ia meneruskan perjuangannya lewat majalah tersebut.

3. Rasuna Said memiliki peran yang sangat penting pada semua pergerakan organisasi yang sempat ia ikuti. Salah satunya adalah sebagai penulis di Partai Sarikat Islam Indonesia (PSII) dan juga sebagai seksi propaganda di partai PERMI. Bahkan di PERMI Rasuna Said mendapat julukan "Singa Betina" oleh polisi pemerintah Belanda yaitu PID (politieke Inlichtingen Dlesnst) sebab pidato-pidatonya. Pidatopidato Rasuna Said yang terkenal lugas dan lantang. Rasuna Said sempat dipenjarakan oleh kepolisian Belanda pada saat itu. Setelah masa hukumannya kemudian Rasuna Said masuk ke dalam sebuah majalah "Raya" sebagai pimpinan redaksi. Sebab terkenalnya majalah "Raya" ini hingga membuat PERMI pada tahun 1937 yang kemudian membuat Rasuna pergi ke Kota Medan. Rasuna Said berjuang sendirian di Kota Medan dengan membuat sebuah majalah bernama "Menara Putri" yang mengkritik pemerintah Hindia Belanda lebih keras dari pada majalah sebelumnya yaitu "Raya". Ketika di masa kependudukan Jepang Rasuna mendirikan "Pemuda Nippon Raya" Bersama Chotib Sulaeman bekerjasama dengan pemerintah Jepang. Cita-cita dasar "Pemuda Nippon Raya" untuk kemerdekaan Indonesia, setelah cita-cita yang diketahui oleh Jepang kemudian pemerintah Jepang membubarkan "Pemuda Nippon Raya". Kemudian pemerintah Jepang mendirikan Gyu Gun di mana Rasuna Said sebagai pemimpin bagian putri dengan nama "Butuh lbu Pusat Laskar Rakyat", Rasuna said juga aktif dalam propaganda, khususnya untuk membentuk kader perjuangan bangsa. 


\section{Kalpataru, Volume 7, Nomor 2, Desember 2021 (153-160)}

4. Dalam nilai dari pemikiran Rasuna Said berpikiran adalah tentang wanita, nasionalisme, dan persatuan.

\section{DAFTAR PUSTAKA}

Esti, Nurjanah. 2017. "Peran Hajjah Rangkayo Rasuna Said dalam Memperjuangkan Hak-hak Perempuan Indonesia (19261965)". Skripsi. Fakultas IImu Sosial. Jurusan Pendidikan Sejarah. Universitas Negeri Yogyakarta. Yogyakarta.

Gottschalk, Louis. 1986. Mengerti Sejarah. Jakarta: Yayasan Penerbit UI.

Jahroni, Jajang. 2002. Ulama Perempuan Indonesia. Jakarta: PT Gramedia Pusaka Utama-PPIM IAIN Jakarta.

Kahin, Audrey. 2008. Dari Pemberontakan Ke Integrasi Sumatera Barat dan Politik Indonesia 1926-1998. Jakarta: Yayasan Obor Indonesia.

Kamajaya. 1984. Sembilan Srikandi Pahlawan Nasional. Yogyakarta: UP Indonesia.
Kartodirjo, Sartono. 1982. Pemikiran dan Perkembangan Historiografi Indonesia SuatuAlternatif. Jakarta: Gramedia.

Kowani. 1978. Sejarah Setengah Abad Pergerakan Wanita Indonesia. Jakarta: PN Balai Pustaka.

Kuntowijoyo. 1999. Pengantar IImu Sejarah. Yogyakatra: Yayasan Benteng Budya.

Martamin, Mardjani dkk. Sejarah Kebangkitan Nasional Daerah Sumatera Barat. Jakarta: Departemen Pendidikan dan Kebudayaan.

Putra, Purwanto. 2019. 7 Tokoh Nasional Sumatera Barat dibidang Pendidikan dan Pers. Depok: Yayasan Petualang Literasi.

Sally, White. 2013. Rasuna Said: Lioness of the Indonesian Independence Movement. Singapore: NUS Press.

Sjamsuddin, H. 1996. Metode Sejarah. Jakarta: Depdikbud, Proyek Pendidikan Tenaga Akademik.

Widi, Astuti. 2013. Perempuan Pejuang Jejak Perjuangan Perempuan Islam Nusantara dari Masa ke Masa. Bandung: Konstanta Publishing House. 


\section{KETENTUAN PENULISAN ARTIKEL JURNAL KALPATARU}

1. Naskah berbahasa Indonesia yang disempurnakan bertemakan kesejarah yang meliputi hasil penelitian sejarah, pengajaran sejarah dan penelitian kebudayaan.

2. Naskah harus asli dan belum pernah dimuat dalam media lain. Naskah dapat berupa hasil penelitian/artikel kajian konseptual yang ditulis oleh perorangan dan atau kelompok.

3. Naskah ditulis dengan cara-cara yang sesuai dengan ketentuan penulisan artikel ilmiah menggunakan bahasa Indonesia yang baku, berupa ketikan, beserta soft file dalam CD-RW atau dengan mengirimkan email pada redaksi jurnal Kalpataru dengan alamat jurnalkalpatarusejarah@gmail.com, spasi tunggal, jenis huruf arial narrow ukuran 12, dengan panjang naskah antara 8-15 halaman pada kertas A4.

4. Artikel hasil penelitian memuat:

JUDUL

Nama Penulis

Abstrak

\section{: XXX (HURUF KAPITAL)}

: (disertai jabatan, institusi, dan email)

: (Bahasa Indonesia yang memuat 100-200 kata diikuti kata kunci, dengan jenis huruf arrial narrow dan ukuran huruf 11 serta dicetak miring). masalah penelitian, dan tujuan penelitian).

\section{B. METODE PENELITIAN}
: (memuat latar belakang masalah, tinjauan pustaka secara ringkas,
A. PENDAHULUAN

C. HASIL DAN PEMBAHASAN

D. SIMPULAN

: (berisi simpulan).

DAFTAR PUSTAKA : : (berisi pustaka yang dirujuk dalam uraian naskah).

5. Artikel Kajian Konseptual memuat:
JUDUL
: XXX (HURUF KAPITAL)
Nama Penulis
Abstrak
: (disertai jabatan, institusi, dan email)
: (Bahasa Indonesia yang memuat 100-200 kata diikuti kata kunci, dengan jenis huruf arrial narrow dan ukuran huruf 11 serta dicetak miring.
PENDAHULUAN
: (memuat latar belakang masalah, tinjauan pustaka secara ringkas, masalah penelitian, dan tujuan penelitian).
Sub Judul
: Sesuai dengan kebutuhan (tanpa numbering).
Simpulan
DAFTAR PUSTAKA
: (berisi simpulan dan saran).

6. Referensi sumber dalam teks artikel ditulis dengan menggunakan side note, contoh (Jalaludin, 1991:79); sementara penulisan daftar pustaka disusun dengan ketentuan. Nama pengarang. Tahun terbit. Judul (dicetak miring). Kota terbit: Nama Penerbit. Contoh: Koentjaraningrat. 2010. Manusia dan Kebudayaan di Indonesia. Jakarta: Djambatan. Daftar pustaka hanya memuat pustaka/sumber yang dirujuk dalam uraian dan disusun menurut abjad tanpa nomor urut.

7. Naskah yang dimuat akan disunting kembali oleh redaksi tanpa mengubah isinya.

8. Naskah yang ditolak (tidak bisa dimuat) akan dikirim kembali ke penulis dengan pemberitahuan tertulis dari redaksi atau melalui email.

9. Penulis yang naskahnya dimuat akan mendapat 1 (satu) majalah nomor yang bersangkutan.

10. Kontak person: Muhamad Idris (081271498618); Eva Dina Chairunisa (082281267851); Jeki Sepriady (085269261780). 